\title{
TETROPIUM KIRBY, 1837 (INSECTA, COLEOPTERA, CERAMBYCIDAE): PROPOSED CONSERVATION BY THE SUPPRESSION OF ISARTHRON DEJEAN, 1835. Z.N.(S.)2534
}

By Maciej Mroczkowski (Instytut Zoologii Polska Akademia Nauk, ul. Wilcza 64, Warszawa, Poland)

The purpose of this application is to suppress a generic name not used during the last hundred years which is a senior subjective synonym of a very well known generic name, Tetropium Kirby, 1837.

2. In 1835 Dejean introduced two generic names: Criomorphus (p. 337) and Isarthron (p. 329). Criomorphus is unavailable (Dejean included only one species, curtus - a nomen nudum), but Isarthron is an available name (Dejean included three previously described species under eight names). The type species of Isarthron is Callidium aulicum Fabricius, 1775 (Syst. Ent., p. 190), designated by Linsley (1962, p. 85). Criomorphus was described by Mulsant (1839, p. 58), type species, by monotypy, Callidium aulicum Fabricius, 1775; however, this is not only a junior objective synonym of Isarthron but also a junior homonym of Criomorphus Curtis, 1829 (p. 194) (Hemiptera).

3. In 1837 Kirby (p. 174) described the genus Tetropium. The type species, designated by Thomson $(1864$, p. 266$)$, is Tetropium cinnamopterum Kirby, 1837.

4. L. Redtenbacher $(1845$, p. 110$)$ gave the description of Isarthron (on p. 153 Dejean is cited as author) but without associated nominal species. In all subsequent systematic works prior to Linsley, 1962, Redtenbacher (with date 1845) is wrongly cited as the author of the name Isarthron, which is treated as a junior synonym of Tetropium Kirby, 1837. Neave (1939, Nomencl. Zool., II, p. 785) likewise treats Isarthron Dejean, 1835 as a nomen nudum and cites Redtenbacher (1845) as the author.

5. L. Agassiz (1846) emended Isarthron Dej. to Isarthrum. Isarthrum Agassiz, 1846 is, as an unjustified emendation, a junior objective synonym of Isarthron Dej.

6. Whenever (as has been the case) Callidium aulicum Fabricius, 1775 (type species of Isarthron Dejean, 1835) and Tetropium cinnamopterum Kirby, 1837 (type species of Tetropium Kirby, 1837) are held to be congeneric, Isarthron and Tetropium are subjective synonyms.

7. Only Linsley (1962, p. 85) has stated that Dejean's name Isarthron is available and has priority over Tetropium Kirby, but nevertheless even he treated Tetropium Kirby as the valid name in his monograph. In accordance with Art. 79(c)(2) of the Code, the following is a selection of 10 different publications in which Tetropium Kirby has been used as a valid name:

1955 Heyrovsky, L., Tesarikoviti - Cerambycidae. In: Fauna ČSR, vol. 5. Praha, (on p. 148). 
1961 Panin, S. \& Savulescu, N. Cerambycidae (Croitori). In: Fauna Republicii Populare Romine. Insecta. Vol. X, fasc. 5. Bucuresti, (on p. 219).

1962 Linsley, E. G. The Cerambycidae of North America. Part II. Univ. Calif. Publ. Ent., Berkeley and Los Angeles. Vol. 19. (on p. 85).

1966 Demelt, C. Cerambycidae. In: Die Tierwelt Deutschlands. 52. Teil. Jena, (on p. 54).

1966 Harde, K. W. Cerambycidae. In: Die Käfer Mitteleuropas, Vol. 9. Krefeld, (on p. 16).

1973 Allenspach, V. Cerambycidae. In: Insecta Helvetica Catalogus. Vol. 3. Zürich, (on p. 28).

1974 Horion, A. Faunistik der Mitteleuropäischen Käfer. Vol. 12. Überlingen-Bodensee, (on p. 10).

1978 Klausnitzer, B. \& Königstedt, D. Die Bockkäfer Mitteleuropas. Cerambycidae. (Die Neue Brehm-Bücherei). Wittenberg. (on p. 161).

1979 Silfverberg, H. (editor) 1979. Enumeratio Coleopterorum Fennoscandiae et Daniae. Helsinki, (on p. 54).

1981 Lobanov, A. L., Danilevsky, M. L. \& Murzin, S. V. Systematic list of longicorn beetles (Coleoptera, Cerambycidae) of the USSR. Part I. Ent. Obozr., Leningrad, Vol. 60, (on p. 803).

8. The International Commission on Zoological Nomenclature is, for the reasons above, asked:

(1) to use its plenary powers to suppress the generic name Isarthron Dejean, 1835, for the purposes of the Principle of Priority;

(2) to place on the Official List of Generic Names in Zoology the name Tetropium Kirby, 1837 (gender: neuter), type species, by subsequent designation by Thomson, 1864, Tetropium cinnamopterum Kirby, 1837;

(3) to place on the Official List of Specific Names in Zoology the name cinnamopterum Kirby, 1837, as published in the binomen Tetropium cinnamopterum (specific name of the type species of Tetropium Kirby, 1837);

(4) to place on the Official Index of Rejected and Invalid Generic Names in Zoology the name Isarthron Dejean, 1835, suppressed under the plenary powers in (1) above.

\section{REFERENCES}

AGASSIZ, J. L. R. 1846. Nomenclatoris zoologici Index universalis. Soloduri, $\mathrm{VIII}+393 \mathrm{pp}$.

CURTIS, J. 1829. A guide to an arrangement of British insects. London, VI pp. + 256 columns $+1 \mathrm{p}$.

DEJEAN, P. F. M. A. 1835. Catalogue des Coléoptères. Ed. $2(=3), 4^{\mathrm{e}}$ livraison. Paris, pp. 257-360. 
FABRICIUS, J. Ch. 1775. Systema Entomologiae. Flensburgi et Lipsiae, $32+832$ $\mathrm{pp}$.

KIRBY, W. 1837. In RICHARDSON, Sir J. (Ed.): Fauna Boreali-Americana. Part 4: Insects. Norwich.

LINSLEY, E. G. 1962. The Cerambycidae of North America. Part II. Univ. Calif. Publ. Ent., Berkeley and Los Angeles, vol. 19, V+103 pp., 1 t., $34 \mathrm{ff}$.

MULSANT, E. 1839. Histoire Naturelle des Coléoptères de France, Part I. Longicornes. Paris, $11+364 \mathrm{pp}$.

NEAVE, S. A. 1939. Nomenclator Zoologicus. Vol. II. D.L. London, 1025 pp.

REDTENBACHER, L. 1845. Die Gattüngen der Deutschen Kaefer-Fauna. Wien, $13+178$ pp., 2 tt.

THOMSON, J. 1864. Systema Cerambycidarum. Mém. Soc. R. Sci. Liége, vol. 19, $538 \mathrm{pp}$. 


\section{$2 \mathrm{BHL}$ Biodiversity Heritage Library}

Mroczkowski, M. 1986. "Tetropium Kirby, 1837 (Insecta, Coleoptera, Cerambycidae): proposed conservation by the suppression of Isarthron Dejean, 1835. Z. N. (S.) 2534." The Bulletin of zoological nomenclature 43, 188-190. https://doi.org/10.5962/bhl.part.419.

View This Item Online: https://www.biodiversitylibrary.org/item/45868

DOI: https://doi.org/10.5962/bhl.part.419

Permalink: https://www.biodiversitylibrary.org/partpdf/419

\section{Holding Institution}

Natural History Museum Library, London

\section{Sponsored by}

Natural History Museum Library, London

\section{Copyright \& Reuse}

Copyright Status: In copyright. Digitized with the permission of the rights holder.

License: http://creativecommons.org/licenses/by-nc-sa/3.0/

Rights: https://biodiversitylibrary.org/permissions

This document was created from content at the Biodiversity Heritage Library, the world's largest open access digital library for biodiversity literature and archives. Visit BHL at https://www.biodiversitylibrary.org. 